University for Business and Technology in Kosovo

UBT Knowledge Center

UBT International Conference

2017 UBT International Conference

Oct 28th, 9:00 AM - 10:30 AM

\title{
Comparison of some quality and safety parameters in drinking water in Pollog region
}

\author{
Zhezair Idrizi \\ Universiteti i Tetovës \\ Merita Saliu \\ Universiteti i Tetovës \\ Vigan Sulejmani \\ Universiteti i Tetovës \\ Namik Durmishi \\ Universiteti i Tetovës \\ Gafur Durmishi \\ Universiteti i Tetovës
}

Follow this and additional works at: https://knowledgecenter.ubt-uni.net/conference

Part of the Food Science Commons

\section{Recommended Citation}

Idrizi, Zhezair; Saliu, Merita; Sulejmani, Vigan; Durmishi, Namik; and Durmishi, Gafur, "Comparison of some quality and safety parameters in drinking water in Pollog region" (2017). UBT International Conference. 164.

https://knowledgecenter.ubt-uni.net/conference/2017/all-events/164

This Event is brought to you for free and open access by the Publication and Journals at UBT Knowledge Center. It has been accepted for inclusion in UBT International Conference by an authorized administrator of UBT Knowledge Center. For more information, please contact knowledge.center@ubt-uni.net. 


\title{
Comparison of some qualitv and safetv parameters in drinking water in Pollog region
}

\author{
Xhezair Idrizi ${ }^{1}$, Merita Saliu $^{1}$, Vigan Sulejmani $^{1}$, Durim Alija $^{1}$, Merije Elezi $^{1}$ \\ ${ }^{1}$ Universiteti i Tetovës
}

\begin{abstract}
Water is essential for its life, without water the life on Earth would not exist. Water is the main component of the cells comprising from about $70 \%$ to about $95 \%$ of the cellular mass or organisms. This means that we are made up of about $80 \%$ of our bodies by water, and even some special organisms, such as eg, contain up to $96 \%$ water. Water contains simultaneously the environment and the outside in which live many live forms, as noted above, about $75 \%$ of our planet is covered by water. Water, thanks to some of the above-mentioned properties, has such thermal properties that disintegrate as cell stabilizers and the organism in general.
\end{abstract}

Keywords: Water, parameters, region, water network.

\section{WORKING METHOD}

The samples are taken in the Gostivar and Tetovo regions, samples were analyzed in time, day (4-8 h), within 3 days in the region, in the water supply system of Pollog region. During the review and preliminary analyzes made in the Polog region by analyzing the physical, chemical and bacteriological parameters from the Public Health Institute of the Republic of Macedonia, the center of Gostivar and Tetovo, the data were extracted and acquired.

\section{PRESENTATION OF RESULTS}

The experimental results of research in the area of the Municipality of Gostivar and Tetovo are presented in the following tables. The results obtained from the samples are compared with the Official Gazette of the Republic of Macedonia.

\section{PRESENTATION OF RESULTS}


Table 1. Results of physical and chemical analyzes of drinking water in the region of Gostivar for the period from 01.01.2015 to 31.12.2015.

\begin{tabular}{|c|c|c|c|c|c|c|c|c|c|}
\hline \multirow{2}{*}{\multicolumn{4}{|c|}{ Public Health Center-Tetovo }} & \multicolumn{6}{|c|}{ Number of tests performed } \\
\hline & & & & \multicolumn{3}{|c|}{ Physical and chemical } & \multicolumn{3}{|c|}{ Bacteriological } \\
\hline & $\begin{array}{l}\text { Resid } \\
\text { ent }\end{array}$ & $\begin{array}{l}\text { Surv } \\
\text { ey }\end{array}$ & $\begin{array}{l}\text { Exa } \\
\text { mpl }\end{array}$ & & \multicolumn{2}{|c|}{ Non right } & $\begin{array}{c}\begin{array}{c}\text { In } \\
\text { gener }\end{array} \\
60\end{array}$ & \multicolumn{2}{|c|}{ Non right } \\
\hline $\begin{array}{l}\text { Civic } \\
\text { Settlements }\end{array}$ & $\begin{array}{c}49.54 \\
5\end{array}$ & 4 & 60 & 38 & 9 & $23.6 \%$ & & 3 & $5 \%$ \\
\hline $\begin{array}{l}\text { City Water } \\
\text { Supply }\end{array}$ & -- & 4 & 58 & 36 & 36 & $25.0 \%$ & 58 & 3 & $5.2 \%$ \\
\hline $\begin{array}{ll}\text { Local water } \\
\text { supply }\end{array}$ & -- & 0 & 1 & 1 & 0 & 0 & 1 & 0 & 0 \\
\hline $\begin{array}{l}\text { Individual } \\
\text { water supply }\end{array}$ & & 0 & 1 & 1 & 0 & 0 & 1 & 0 & 0 \\
\hline $\begin{array}{l}\text { Rural } \\
\text { settlements }\end{array}$ & $\begin{array}{c}68.18 \\
4\end{array}$ & 50 & 308 & 303 & 60 & $19.8 \%$ & 308 & 58 & $18.8 \%$ \\
\hline $\begin{array}{l}\text { Key villages } \\
\text { in the city }\end{array}$ & $\begin{array}{c}1157 \\
5\end{array}$ & 9 & 43 & 42 & 10 & $23.8 \%$ & 43 & 2 & $4.6 \%$ \\
\hline $\begin{array}{l}\text { The main } \\
\text { water supply } \\
\text { of the villages }\end{array}$ & $\begin{array}{c}51.78 \\
9\end{array}$ & 32 & 205 & 203 & 40 & $19.7 \%$ & 205 & 44 & $21.5 \%$ \\
\hline $\begin{array}{l}\text { Central local } \\
\text { water supply }\end{array}$ & 4.820 & 9 & 48 & 46 & 4 & $8.7 \%$ & 48 & 6 & $12.5 \%$ \\
\hline $\begin{array}{l}\text { Individual } \\
\text { water supply }\end{array}$ & -- & 0 & 12 & 12 & 6 & $50.0 \%$ & 12 & 6 & $50.0 \%$ \\
\hline $\begin{array}{l}\text { Vacations } \\
\text { hotels }\end{array}$ & -- & & 18 & 17 & 2 & $11.8 \%$ & 18 & 6 & $33.3 \%$ \\
\hline $\begin{array}{l}\text { Employer } \\
\text { organizations }\end{array}$ & -- & & 29 & 28 & 4 & $14.8 \%$ & 29 & 0 & 0 \\
\hline Other objects & & 30 & 35 & 34 & 6 & $17.6 \%$ & 35 & 4 & $11.4 \%$ \\
\hline In general & $\begin{array}{c}1177 \\
29\end{array}$ & 84 & 450 & 420 & 81 & $19.3 \%$ & 450 & 71 & $15.8 \%$ \\
\hline
\end{tabular}

From the parameters listed in Table 2, which shows that in the period from 01.01.2015 to 31.12.2015, the center for general health Tetovo, the center in Gostivar as well as those of the town and those of the village has 84 field centers from where they are taken 420 samples of drinking water for physical and chemical analysis from which $81(19.3 \%)$ were not physical and chemical rights and 450 samples of water for bacteriological analyzes from which 71 samples $(15.8 \%)$ were not bacteriological. In the same period from the settlements around, 38 samples of drinking water for physical and chemical analysis were obtained from where 9 or $23.6 \%$ were unfair and 60 samples of bacteriological drinking water samples from where 3 samples or 5\% were not right from the bacteriological point of view 
Content of physical and chemical parameters of drinking water for the period from 01.01.2015 to 31.12.2015

Table 2. Content of physical and chemical parameters of drinking water for the period from 01.01.2015 to 31.12.2015

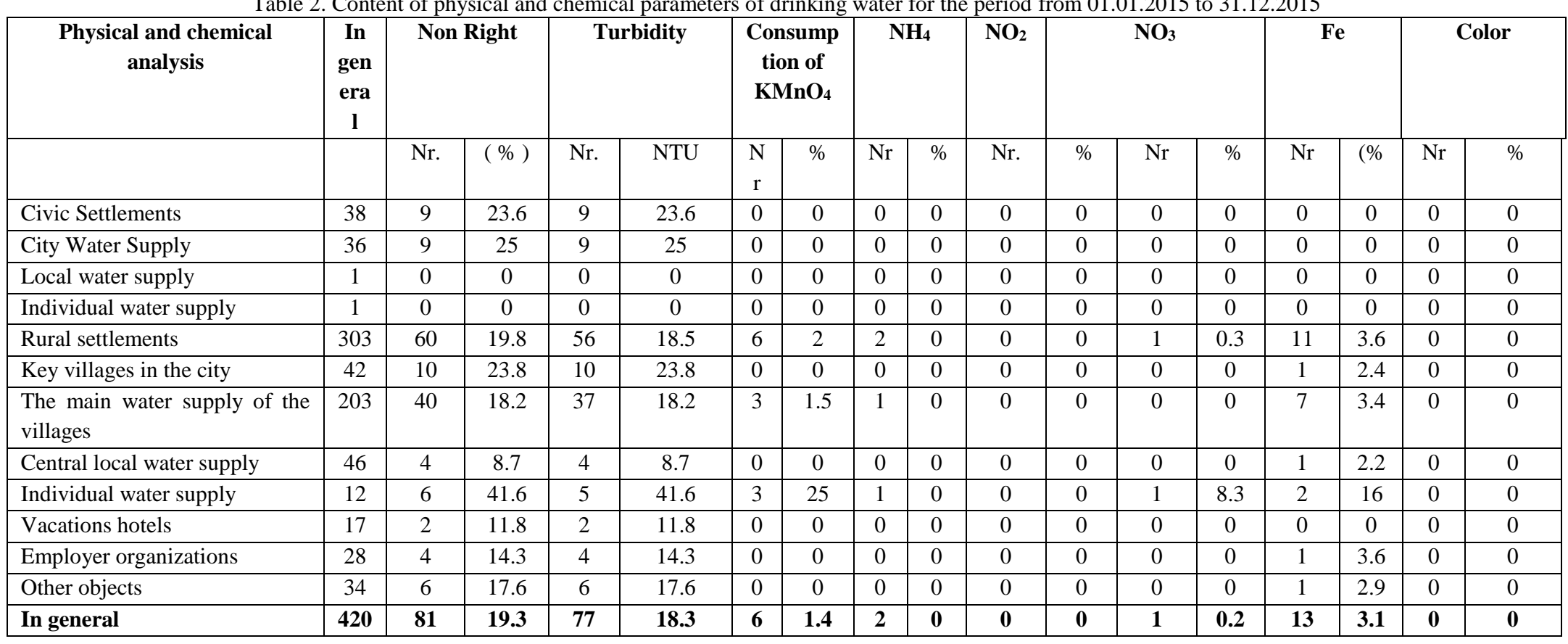

Table 2 shows that from January 1, 2015 to December 31, 2015, the physical and chemical parameters higher than those with non-right waters are turbidity $(18.3 \%)$, followed by iron content $(3.1 \%)$, consumption potassium permanganate $(1.4 \%)$, ammonia $(0.5 \%)$ and nitrates $(0.2 \%)$. 


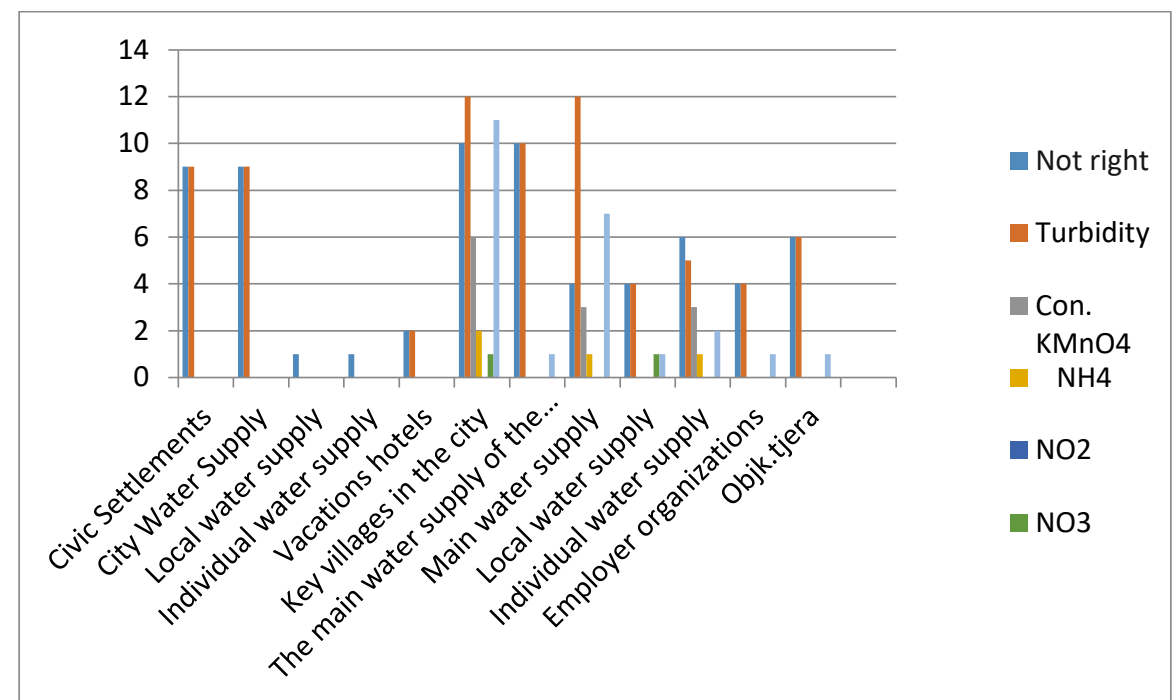

Fig 1-Content of physical and chemical parameters of drinking water from 01.01-31.12.2015

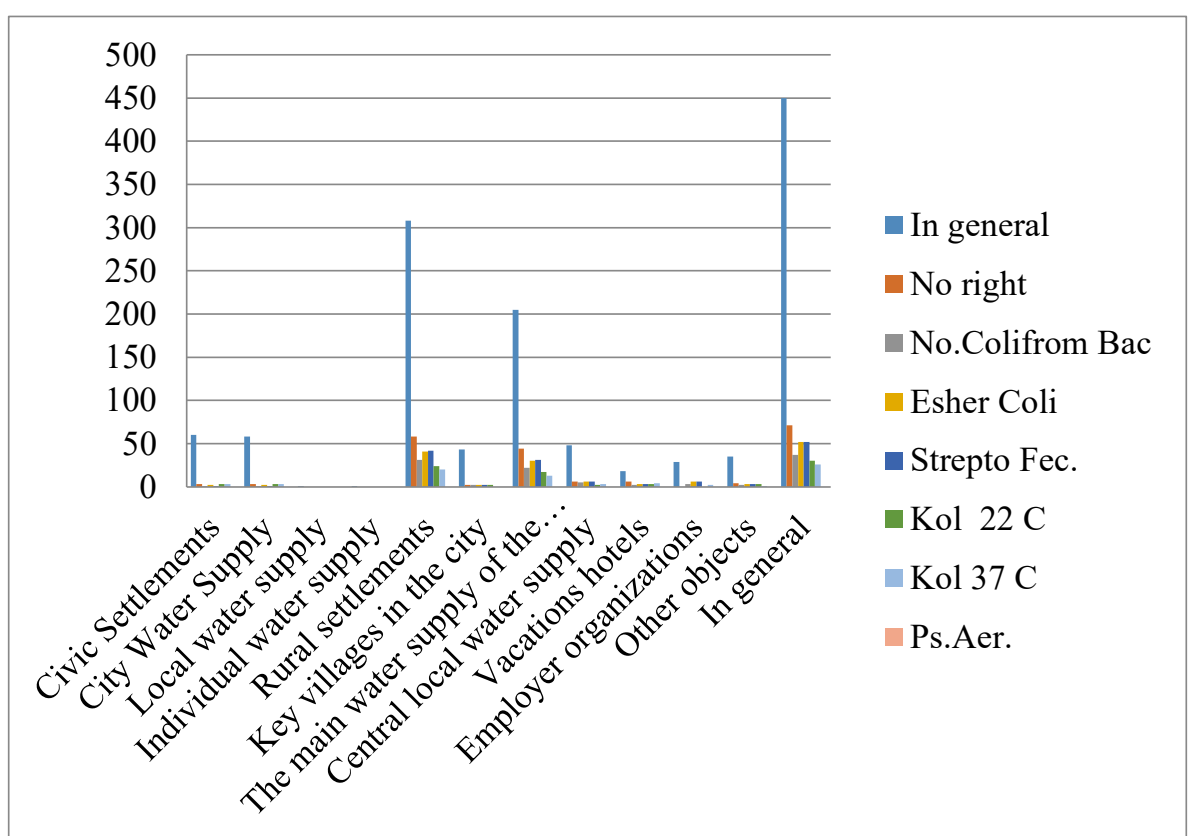

Fig. 2- Bacteriological parameters of drinking water for the period from 01.01-31.12.2015

From bacteriological parameters (Table 3), 52 examples of drinking water (11.5\%) are not accurate for E-coli and Streptococcus facial parameters, 37 examples $(8.2 \%)$ in coliform bacteria, 30 examples $(6.7 \%)$ from columns at $220 \mathrm{C}$ and 26 examples $(5.8 \%)$ are not fair from the number of columns at $37^{\circ} \mathrm{C}$. 
Content of incorrect bacteriological parameters examples of drinking water for the period from 01.01.2015 to 31.12.2015.

\begin{tabular}{|c|c|c|c|c|c|c|c|c|c|c|c|c|c|c|c|}
\hline \multirow[t]{2}{*}{$\begin{array}{l}\text { Bacteriological } \\
\text { analysis }\end{array}$} & \multirow[t]{2}{*}{ General } & \multicolumn{2}{|c|}{ Not right } & \multicolumn{2}{|c|}{$\begin{array}{l}\text { Nr. } \\
\text { coliform } \\
\text { bacteria }\end{array}$} & \multicolumn{2}{|c|}{ Eschericha Coli } & \multicolumn{2}{|c|}{$\begin{array}{l}\text { Streptococus } \\
\text { Fekalis }\end{array}$} & \multicolumn{2}{|c|}{$\begin{array}{l}\text { Number of } \\
\text { colonies in } 22^{0} \mathrm{C}\end{array}$} & \multicolumn{2}{|c|}{$\begin{array}{c}\text { Number of } \\
\text { colonies at } \\
37^{\circ} \mathrm{C}\end{array}$} & \multicolumn{2}{|c|}{$\begin{array}{l}\text { Pseudomon } \\
\text { as } \\
\text { Aeruginosa }\end{array}$} \\
\hline & & $\mathrm{Nr}$. & $\%$ & Nr. & $\%$ & $\mathrm{Nr}$. & $\%$ & Nr. & $\%$ & $\mathrm{Nr}$. & $\%$ & Nr. & $\%$ & Nr. & $\%$ \\
\hline Civic Settlements & 60 & 3 & 5 & 1 & 1.7 & 2 & 3.3 & 1 & 1.7 & 3 & 5 & 3 & 5 & 0 & 0 \\
\hline City Water Supply & 58 & 3 & 5.2 & 1 & 1.7 & 2 & 3.4 & 1 & 1.7 & 3 & 5.2 & 3 & 5.2 & 0 & 0 \\
\hline Local water supply & 1 & 0 & 0 & 0 & 0 & 0 & 0 & 0 & 0 & 0 & 0 & 0 & 0 & 0 & 0 \\
\hline Individual water supply & 1 & 0 & 0 & 0 & 0 & 0 & 0 & 0 & 0 & 0 & 0 & 0 & 0 & 0 & 0 \\
\hline Rural settlements & 308 & 58 & 18.8 & 31 & 10 & 41 & 13.3 & 42 & 13.6 & 24 & 7.8 & 20 & 6.5 & 0 & 0 \\
\hline Key villages in the city & 43 & 2 & 4.6 & 2 & 4.6 & 2 & 4.6 & 2 & 4.6 & 2 & 4.6 & 0 & 0 & 0 & 0 \\
\hline $\begin{array}{l}\text { The main water supply } \\
\text { of the villages }\end{array}$ & 205 & 44 & 21.5 & 22 & 10.7 & 30 & 14.6 & 31 & 15.1 & 17 & 8.3 & 13 & 6.3 & 0 & 0 \\
\hline $\begin{array}{l}\text { Central local water } \\
\text { supply }\end{array}$ & 48 & 6 & 12.5 & 5 & 10.4 & 6 & 12.5 & 6 & 12.5 & 2 & 4.2 & 3 & 6.3 & 0 & 0 \\
\hline Individual water supply & 12 & 6 & 50 & 2 & 16.6 & 3 & 25 & 3 & 25 & 3 & 25 & 4 & 33.3 & 0 & 0 \\
\hline Vacations hotels & 18 & 6 & 33.3 & 3 & 16.6 & 6 & 33.3 & 6 & 33.3 & 0 & 0 & 2 & 11.1 & 0 & 0 \\
\hline Employer organizations & 29 & 0 & 0 & 0 & 0 & 0 & 0 & 0 & 0 & 0 & 0 & 0 & 0 & 0 & 0 \\
\hline Other objects & 35 & 4 & 11.4 & 2 & 5.7 & 3 & 8.6 & 3 & 8.6 & 3 & 8.6 & 1 & 2.9 & 0 & 0 \\
\hline In general & 450 & 71 & 15.8 & 37 & 8.2 & 52 & 11.5 & 52 & 11.5 & 30 & 6.7 & 26 & 5.8 & $\mathbf{0}$ & $\mathbf{0}$ \\
\hline
\end{tabular}




\section{CONCLUSION}

1. Based on the physical and chemical results obtained in the drinking water in the region of Gostivar, for the period from 01.01.2015 to 31.12.2015, as water of the highest quality based on the turbidity parameter results local water supply samples, individual water supply with 0 NTU score whereas with the highest score of NTU 41.6 result, samples from individual water supply from village network;

2. Based on the results obtained from the bacteriological point of view, 52 samples of drinking water $(11.5 \%)$ were not regular according to the Escherichia coli and streptococusfecalis parameters, 37 samples $(8.2 \%)$ were not regular based on the colon parameter at $22{ }^{\circ} \mathrm{C}$ and 26 samples $(5.8 \%)$ are irregular for the number parameter in colonies at $37^{\circ} \mathrm{C}$. As evidenced by the safer bacteriological aspect, the samples were sampled in local and individual waterworks as well as samples as employers' organizations.

3. As a final conclusion we can conclude that both the physical and the microbiological aspects the analyzed waters are safe and show no signs of danger, so they are allowed to drink.

\section{REFERECES}

1. Lester Brown, State of the World, 7, (2001).

2. BožoDalmacija (redakator), Kontrolakvalitetavoda, Univerzitet u NovomSadu, Insitutza Hemiju, Kadetrazahemijskutehnologijuizaštituživotnesredine, 2001.

3. Nexhat M. Daci, Kimia e mjedisit (ndotjaindustriale - parandalimi), Akademia e Shkencavedhe e Arteve e Kosovës, Botime të veçanta XXVIII, SeksioniiShkencave të Natyrës, Libri 5, Prishtinë, 1998.

4. Gazeta zyrtare e R. Maqedonisë, Nr. 18, 1999.

5. Coetzee, J.F., Hussam, A., Petrick, T.R. (1983), Extension of potentiometric stripping

6. Frenzel, W., Bratter, P. (1986), Flow-injection potentiometric stripping analysis - A new concept for fast trace determinations, Anal.Chim.Acta.

7. Dr. sc. BardhaKorça, Analizakimike e ujit, Donacionii MASHTK\&wusaustria, Prishtinë. 2003.

8. Dh.Haxhimihajli:Teknologjiakimike inorganike, Tiranë-1980.

9. Filipoviq,S.Lipanoviq:Kimia e përgjithshmedheinorganike (pjesa e dytë)

10. DhurataBozo:Teknologjia e ujit,uji si ingredient në industrin ushqimore,Tiranë-2010

11. I.Hashani,T.Gjejqibitriqi.Kimiapraktikum,Prishtinë 1997.

12. M.Rugova,T.Gjejqibitriqi.Kimiainorganike,Prishtinë 1998.

13. B.H.Durmishi,, Përcakrtimi i shkallës së ndotjes së ujërave të lumit shkumbin”, 2005. 